\title{
The Evolution of
}

International Human Rights

Third Edition 


\section{Pennsylvania Studies in Human Rights}

Bert Lockwood, Jr., Series Editor

A complete list of books in the series is available from the publisher. 


\section{The Evolution of International Human Rights}

Visions Seen

THIRD EDITION

Paul Gordon Lauren

\section{$\overline{\text { PENN }}$}

University of Pennsylvania Press

Philadelphia 
Copyright (C 2011 University of Pennsylvania Press

All rights reserved. Except for brief quotations used for purposes of review or scholarly citation, none of this book may be reproduced in any form by any means without written permission from the publisher.

Published by

University of Pennsylvania Press

Philadelphia, Pennsylvania 19104-4012

www.upenn.edu/pennpress

Printed in the United States of America on acid-free paper

$\begin{array}{llllllllll}10 & 9 & 8 & 7 & 6 & 5 & 4 & 3 & 2 & 1\end{array}$

Library of Congress Cataloging-in-Publication Data

Lauren, Paul Gordon.

The evolution of international human rights : visions seen / Paul

Gordon Lauren.-3rd ed.

p. cm.- (Pennsylvania studies in human rights)

Includes bibliographical references and index.

ISBN 978-0-8122-2138-1 (hardcover : alk. paper)

1. Human rights. I. Title.

JC571.L285 2011

323-dc22 
to my teachers 
This page intentionally left blank 